\title{
Quantitative Determination of drugs \& pharnaceuticalsby using iodine as analytical reagent: A spectrophotometric study
}

\author{
T. Vinod Kumar ${ }^{1}$, M. Seethamma and G. Venkateshwarlu \\ Department of Chemistry, Osmaania Unevrsity, Hyderabad- 500 007, India \\ ${ }^{1}$ Jayaprakash Narayan College of Engineering, Mahabubnagar-509001.
}

\begin{abstract}
Sensitive, accurate and precise methods for the qauantitative determination of Seven drugs viz., Cyclobenzaprine $\mathrm{HCl}(\mathrm{CYC})$, Cyproheptadine $\mathrm{HCl}(\mathrm{CYP})$, Dobutamine $\mathrm{HCl}(\mathrm{DOB})$, Moxifloxacin $\mathrm{HCl}(\mathrm{MOX})$, Pamiprioxole $\mathrm{HCl}(P A M)$, Sumatriptan succinate (SUM) and Trimetazadine $2 \mathrm{HCl}(T R I)$ haave been developed . The methods are based on the charge transfer interqction of iodine with drugs which resulted in the formation of $I_{3}^{-}$ion with absorbtion maximum at $366 \mathrm{~nm}$. The absorbance of the band increased with increasing concentration of the drug and formed basis for the quantitative determination of the drugs. The methods have been validated in terms of ICH guidelines and parameters affecting the absorbance are optimised.The stoichiometry of each of the CT complex is found to be 1:1 by Job's continuous varuiation methodts and the formation constants are determined by drawing tangents to the Job's plots
\end{abstract}

Key words: Drugs; Determinatio; Iodine ; spectrophotometry;validation

\subsection{Cyclobenzaprine $\mathrm{HCl}(\mathrm{CYC})$}

\section{Introducion}

Cyclobenzaprine, -(5H-dibenzo[a,d]cyclohepten-5-ylidene)-N,N- dimethyl- 1-propanamine (Fig. 1a), was first introduced in 1977 and is a widely prescribed skeletal muscle relaxant with proven efficacy and safety profile in the treatment of acute muscle spasm, acute cervical strain and myofascial pain in occidental populations $[1,2]$.

The important and recent references reported for quantitative determination of this drug included a vast number of references thus far reported for the assay of the drug and pharmaceuticals $[3,6]$.

\subsection{Cyproheptadine HCl (CYP)}

Cyproheptadine hydrochloride, chemically known as 4-(5H-dibenzo[a,d]-cyclohepten-5-ylidene)-1methylpiperidine hydrochloride (Fig. 1b) is a sedating antihistamine with antimuscarinic, serotoninantagonist, and calcium-channel blocking action in pancreatic islet cells and smooth muscle [7]. It is used to treat some hormonal disorders and may also be used for treating side effects of taking antidepressants [8]. CPH is also used in clinical and veterinary medicine as an antiserotonergic and antihistaminic agent with sedative and anticolinergic effects, as well as to stimulate appetite and weight gain in human and veterinary medicine.

It is important to emphasize that there are a huge number of analytical procedures reported and these references cited almost all earlier methods of analysis of this drug [9-12].

\subsection{Dobutamine HCl (DOB)}

Dobutamine hydrochloride, $\quad \mathrm{C} 18 \mathrm{H} 23 \mathrm{NO} \cdot \mathrm{HCl}, \quad$ chemically: 4-(2-((1-methyl-3-(4hydroxybenzene)propyl)amido) ethyl)-1,2-di-hydroxybenzene hydrochloric salt (Fig. 1c) is an adrenalin receptor concussion medicine indicated obvious curative effect for coronary heart disease, acute miocardial infarction, and expansionary cardiomyopathy [13-14].

The physiological importance of Dobutamine hydrochloride initiated several reports on its determination, both in pharmaceuticals and in biological fluids. Several methods have been employed [15-18] for estimation of this drug.

\subsection{Moxifloxacin $\mathrm{HCl}$}

Moxifloxacin (Fig. 1d]) chemically known as 1-cyclopropyl-6-fluoro-1, 4-dihydro-8-methoxy- 7-[(4aS, 7aS)-octahydro-6H-pyrrolo-[3, 4-b] pyridin-6-yl]-4-oxo- 3-quinolinecarboxylic acid hydrochloride is a new generation, 8-methoxyquinolone derivative of fluoroquinolone antibacterial agent, synthetic, active against a broad spectrum of pathogens, encompassing Gram-negative and Gram-positive bacteria. However, most of fluoroquinolones show miner side effect one of these is skin reaction including photosensitivity. This response is inhibited by co-administration with $\mathrm{H} 2$ receptor antagonist [19-20].

The therapeutic importance of Moxifloxacin required the development of sensitive, simple and reliable methods for industrial quality control of pharmaceutical preparations and clinical monitoring of the drug in 
toxicological studies. It is important to emphasize that there are a large number of analytical procedures reported and these references cited almost all earlier methods of analysis of this drug [21-24].

\subsection{Pramipexole HCl (PAM)}

Pramipexole dihydrochloride (PPD), a nonergot dopamine agonist approved in the US (1997), is used as an antidyskinetic for treatment of Parkinson's disease. Its chemical name is (S)-N6-propyl-4,5,6,7-tetrahydro1,3-benzothiazole-2,6- diaminedihydrochloride (Fig. 1e). The ability of PPD to alleviate the signs and symptoms of Parkinson's disease is supposed to be linked to its ability to stimulate dopamine receptors in the striatum [2526].

Because of its physiological significance, the drug attracted the attention of Scholars. Several analytical methods have been reported for the determination of Pramipexole, either in pharmaceutical preparations or in biological fluids [27-30]. The references cited here have exhaustively enumerated the earlier analytical methods on this drug.

\subsection{Sumatriptan succinate (SUM)}

Sumatriptan succinate is chemically, 3-[2-(dimethylamino) ethyl]-N-methyl-indole-5methanesulfonamide succinate (Fig.1f). Sumatriptan is a selective 5-hydroxytryptne1 receptor subtype agonist. Sumatriptan is a triptan drug including a sulfonamide group for the treatment of migrane headaches [31-32].

Because of physiological significance of Sumatriptan, there is much interest in its determination for the purpose of pharmaceutical quality control. Hence it attracted the attention of pharmaceutical analysts. Literature survey assembled a number of methods, which have been used for analysis of Sumatriptan in bulk and in pharmaceutical preparation, the recent ones being [33-36] which collected a large number of other methods for the analysis of the drug.

An exhaustive survey of literature revealed that no reports are available for quantification of above drugs using Iodine as analytical reagent. This prompted author to develop the same.

\subsection{Trimetazadine $2 \mathrm{HCl}$}

Trimetazidine (TRMZ); 1-[(2,3,4-trimethoxyphenyl)methyl] piperazine dihydrochloride (Fig. 1g) is a clinically effective antianginal agent that has been used in the prophylaxis and management of angina pectoris, and in ischemia of neurosensorial tissues as in Meniere's disease [37]. The antianginal efficacy of TRMZ is comparable to propranolol but it does not reduce cardiac rate-pressure product or coronary blood flow [38].

Because of physiological significance of Trimetazadine, there is much interest in its determination for the purpose of pharmaceutical quality control. Hence it attracted the attention of pharmaceutical analysts. Literature survey assembled a number of methods, which have been used for analysis of Trimetazadine in bulk and in pharmaceutical preparation, the recent ones being [39-42] which collected a large number of other methods for the analysis of the drug.

Through survey of literature revealed that the above mentioned seven drugs have not been quantified by iodine as analytical reagent. The successful results obtaned are reported in the present communication

\section{Experimental}

\subsection{Instruments}

The UV-Vis. spectra required for the study have been recorded on SHIMADZU 140 double beam spectrophotometer, Thermo Nicolet 1000 and also on ELICO 159 UV-Visible single beam spectrophotometers using quartz cells of $10 \mathrm{~mm}$ path length.. A Dhona 200 single pan electrical balance is used for weighing the samples.

\subsection{Materials}

Iodine (BDH, Poole, UK) was twice sublimed and preserved in vacuum desiccators ( $\left.\mathrm{mp} 113.6^{\circ} \mathrm{C}\right)$. The drugs analysed were procured from Dr. Reddy's laboratories, Hetero drugs private limited, Kekule Pharma Limited and Symed laboratories ltd. as gift samples.

Stock solution of iodine, $\left(4.003 \times 10^{-3} M\right)$ in analytical grade 1,2 - dichloroethane was freshly prepared (daily) to avoid errors due to the liberation of iodine. A stock solution of each drug containing $1000 \mu \mathrm{g} \mathrm{ml}^{-1}$ was initially prepared and further diluted to get working concentrations (table 1).

\subsection{About the method}

Iodine forms ion- pair charge transfer complexes with a variety of aromatic, aliphatic and heterocyclic compounds containing lone pair (non - bonding) of electrons on oxygen, sulphur and nitrogen atoms which act as electron donors and iodine itself acts as $\sigma$-acceptor. Bonding involved in iodine is $n-\sigma$ type. Donors are completely transparent to visible light while iodine absorbs at $510 \mathrm{~nm}$. 
Mixing the solutions of iodine and drugs results in a change of violet color of iodine into light brown to pale yellow and as a consequence, absorption spectra exhibited a band at 366nm ( Fig.2). This is attributed due to $\mathrm{I}_{3}{ }^{-}$ion formed by the interaction of iodine with drugs and the same is shown below as Scheme 1.
$\mathrm{D}+\mathrm{I}_{2} \rightarrow$ D. $\mathrm{I}_{2} \quad$ (outer complex )
fast .... 1
D. $\mathrm{I}_{2}$ (outer complex) $\rightarrow\left(\right.$ D.I $\left.^{+}\right) \mathrm{I}^{-}$(inner complex) slow.... 2
$\left(\right.$ D. $\left.\mathrm{I}^{+}\right) \mathrm{I}^{-}($inner complex $)+\mathrm{I}_{2} \rightarrow\left(\right.$ D.I $\left.^{+}\right)+\mathrm{I}_{3}^{-} \quad$ fast... 3

\section{Scheme 1}

The absorbance of the band at 366 is a function of concentration of the drugs and formed a basis for quantitative determination of drugs and attracted the attention of many pharmaceutical analysts [43-52].

\subsection{Method development}

Different aliquots of solution of drugs were transferred to $10 \mathrm{ml}$ calibrated standard flask containing a constant volume of reagent solution and volume was made to $10 \mathrm{ml}$ by the solvent. The concentration of drug was varied (Table 1) so as to produce charge transfer complexes with absorbance between 0.06 to 1.2 absorbance units.

\subsection{Procedure for Assay of pure drug}

To test the accuracy and precision of the methods developed pure sample solutions containing drug in the Beer's law limit were chosen. For this study 4, 8, 12 and $16 \mu \mathrm{g} \mathrm{ml}^{-1}$ of CYC; 4, 8, 12 and $16 \mu \mathrm{g} \mathrm{ml}{ }^{-1}$ of CYP; 4, 8, 12 and $16 \mu \mathrm{g} \mathrm{ml}^{-1}$ of DOB; 80, 160, 240 and $320 \mu \mathrm{g} \mathrm{ml}^{-1}$ of MOX; 4, 8, 12 and $16 \mu \mathrm{g} \mathrm{ml}^{-1}$ of PAM; 8, 16, 24 and $32 \mu \mathrm{g} \mathrm{ml}^{-1}$ of SUM; and 4, 8, 12 and $16 \mu \mathrm{g} \mathrm{ml}^{-1}$ of TRI have been taken.

\subsection{Procedure for analysis of Pharmaceuticals}

\subsubsection{Cyclobenzaprine HCl (CYC)}

Twenty tablets of Flexeril each containing $10 \mathrm{mg}$ of CYC were weighed and finely powdered in a mortar. A quantity of powder equivalent to $100 \mathrm{mg}$ of CYC was weighed accurately and dissolved in $100 \mathrm{ml}$ of double distilled water. The solution was then filtered through Whatman filter paper and neutralized with $\mathrm{NaOH}$. It was extracted into 1,2-Dichloro ethane and was further diluted with the same solvent to get working concentrations of the drug.

\subsubsection{Cyproheptadine HCl (CYP)}

Eighty tablets (Practin-4mg) were powdered, weighed and average weight of the tablets was determined. An amount of powder equivalent to 30mg of CYP was weighed accurately and dissolved in $100 \mathrm{ml}$ of double distilled water. The solution was then filtered through Whatman filter paper and neutralized with $\mathrm{NaOH}$. It was extracted into 1,2-Dichloro ethane and was further diluted with the same solvent to get working concentrations of the drug.

\subsubsection{Dobutamine $\mathrm{HCl}$ (DOB)}

2 vials of Dobutrox injection containing $12.5 \mathrm{mg} / \mathrm{vial}$ of DOB were placed in a boiling tube and neutralized with $\mathrm{NaOH}$ and worked out to get working concentrations of drugs in solution of 1,2-dichloro ethane.

\subsubsection{Moxifloxacin HCl (MOX)}

A tablet of Moxicip-420mg was crushed into powder and worked out as mentioned for earlier tablets to get working concentrations of drugs in solution of 1,2-dichloro ethane.

\subsubsection{Pramipexole HCl (PAM)}

Fifty tablets of Parpex-1mg were crushed into powder and worked out as mentioned for earlier tablets to get working concentrations of drugs in solution of 1,2-dichloro ethane.

\subsubsection{Sumatriptan succinate (SUM)}

The powdered content of two tablets of Sumatriptan-50mg was weighed and worked out as mentioned for earlier tablets to get working concentrations of drugs in solution of 1,2-Dichloro ethane.

\subsubsection{Trimetazadine $2 \mathrm{HCl}$ (TRI)}

Twenty tablets of Carvidon each containing $20 \mathrm{mg}$ of TRI were weighed and powdered. Accurately weighed quantity of tablet powder equivalent to $25 \mathrm{mg}$ of TRI was transferred into $50.0 \mathrm{ml}$ volumetric flask and 
dissolved in $25 \mathrm{ml}$ of double distilled water. The solution was then neutralized with $\mathrm{NaOH}$ and extracted into 1,2-dichloro ethane to get required working concentrations.

\section{Results And Discussion}

\subsection{Construction of calibration curves}

The absorbance of each solution was measured against blank (without drug). The absorbance to concentration of the drug called the relative response has been calculated. The average relative response of five replicates was evaluated. The relative responses falling within $95 \%$ to $105 \%$ of average were only considered for construction of calibration curves (Fig. 3). The limits of Beer's law, slope, intercept, correlation coefficient, molar absorptivity, Sandell's sensitivity, formation constants and regression equation for each drug are tabulated in Table 2.

\subsection{Method validation}

The method developed for quantification of drugs has been validated in terms of precision, accuracy, limit of detection. limit of quantification, linearity, selectivity and ruggedness. Calibration curves were drawn and are used to assess the recovery of the drug. To assess the precision, each experiment was repeated at least 5 times and accuracy is estimated in terms of percent recovery and \%RSD. Excellent percent recovery and RSD being less than 2 for each drug demonstrates accuracy and precision of the methods. Further t-test and F-test values have also been calculated using a standard reference method. The t-test and F-test values are less than their permissible range indicating high accuracy of the methods (Table 3).

Limits of linearity of calibration curves were mentioned in the Table 1 under the title Beer's law limit. To test the selectivity, known excipients of each drug were added to the pure drug sample and recovery experiments were performed. The ruggedness of the method was examined by collecting absorbance data using 3 different instruments and 2 analysts. No significant changes were observed either by change of instrument or analyst, hence the method may be taken as rugged.

\subsection{Optimization of the parameters of quantification}

\subsubsection{Effect of concentration of reagent}

When varying volumes of Iodine $(0.2,0.4,0.6,0.8,1.0,1.2,1.4,1.6,1.8,2.0,2.2,2.4 \mathrm{ml})$ were added to fixed concentration of various drugs viz., $20 \mu \mathrm{g} \mathrm{ml}^{-1}$ of CYP, $22.5 \mu \mathrm{gml}^{-1}$ of CYC, $31.5 \mu \mathrm{g} \mathrm{ml}^{-1}$ of DOB, $450 \mu \mathrm{g}$

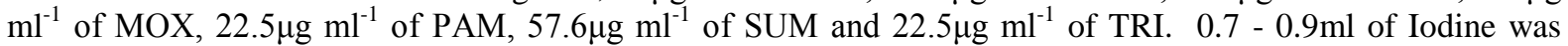
sufficient to produce maximum absorbance after which it remained constant. Hence $1 \mathrm{ml}$ of reagent is used uniformly for all the drugs (Fig 4).

\subsubsection{Effect of time}

The interaction of Iodine with drugs resulted in the formation of colored product which stabilized immediately after mixing. The developed color remained stable at room temperature for about an hour. After two hours many solutions turned purple. After a day all solutions turned black, hence the measurements were made immediately after mixing the solutions.

\subsubsection{Effect of organic solvent}

Various solvents such as carbon tetrachloride, chloroform, 1,2- dichloro ethane, methanol and acetonitrile have been tried to select suitable solvent for the analysis of the drug. 1,2- dichloroethane is found to be the suitable solvent as it produces maximum optical density with a fixed concentration of drug while other solvents mentioned above are found to be unsuitable as they produced lower absorbances due to incomplete dissociation of complex. Methanol and acetonitrile turned Iodine brown even before addition of any drug. Hence 1,2- dichloroethane is used throughout the work.

\subsubsection{Determination of stochiometry}

The stochiometry of each of the complexes has been determined from Job's continuous variation method and found to be 1:1 in each case (Fig. 5). The Job's plots have also been used to evaluate the formation constants of complexes[53,54].

\subsubsection{Analysis of pharmaceuticals}

To test the applicability of the method developed, solutions of pharmaceutical tablets containing drug in the Beer's Law limit were chosen and charge transfer complexation was studied. For this study 4, 8, 12 and $16 \mu \mathrm{g} \mathrm{ml}^{-1}$ of CYC; 4, 8, 12 and $16 \mu \mathrm{g} \mathrm{ml}^{-1}$ of CYP; 4, 8, 12 and $16 \mu \mathrm{g} \mathrm{ml}^{-1}$ of DOB; 80, 160, 240 and $320 \mu \mathrm{g} \mathrm{ml}^{-}$ ${ }^{1}$ of MOX; 4, 8, 12 and $16 \mu \mathrm{g} \mathrm{ml}^{-1}$ of PAM; 8, 16, 24 and $32 \mu \mathrm{g} \mathrm{ml}^{-1}$ of SUM; and 4, 8, 12 and $16 \mu \mathrm{g} \mathrm{ml}^{-1}$ of TRI were chosen for charge transfer complexation other experimental details being common. To assess the precision 
and accuracy, each tablet analysis was repeated at least 5 times and accuracy is estimated in terms of percent recovery and percent RSD. Excellent percent recovery and RSD being less than 2 for each drug demonstrates applicability of the methods for pharmaceutical analysis. Further t-test and F-test values have also been calculated using a standard reference method. The t-test and F-test values are less than their permissible range indicating excellent applicability of the methods for pharmaceutical analysis (Table 4). The excellent recovery studies indicate that methods developed can be applied to pharmaceutical analysis without hesitation.

Sandell's sensitivity of the analyte capable of producing a change 0.001 absorbance units is a measure of sensitivity of the method. Lower the Sandell's sensitivity higher is the sensitivity of the method developed. Sandell's sensitivity values of drugs presented in Table 18 indicate CYC has the lowset Sandell's sensitivity and hence has the highest sensitivity towards the method, they are in the order CYC $<$ DOB $<$ CYP $<$ TRI $<$ $\mathrm{PAM}<\mathrm{SUM}<\mathrm{MOX}$.

\section{Conclusions}

Iodine is found suitable for the analysis of drugs and acts as analytical reagent through charge transfer complexation. The stoichiometry is found to be $1: 1$. The factors effecting the optical density have beeen optimised and methods developed are applied to the analysis of both drugs and pharmaceuticals

\section{Acknowkedgements}

The authors thank the Head, Department of Chemistry and Principal, Nizam Coege, for the facilities. They are also thankful to SERO, UGC, Imdia for the financial support.

\section{References}

[1]. Borenstein, D.G.; Korn, S. Clinical Therapeutics, Efficacy Of A Low-Dose Regimen of Cyclobenzaprine Hydrochloride in Acute Skeletal Muscle Spasm: Results of Two Placebo-Controlled Trials (2003), 25(4), 1056-1073.

[2]. Browning, R.; Jackson, J. L.; O’Malley, P. G. ,Archiev Internal Medicine, Cyclobenzaprine and Back Pain: A Meta-Analysis (2001), 161, 1613-1620.

[3]. Coulter, C.; Taruc, M.; Tuyay, J.; Moore, C. Journal of Analytical,Toxicology, Antidepressant Drugs in Oral Fluid Using Liquid Chromatography-Tandem Mass Spectrometry (2010), 34(2), 64-72.

[4]. Constanzer, M.; Chavez, C.; Matuszewski, B. Journal of Chromatography B, Development and comparison of high-performance liquid chromatographic methods with tandem mass spectrometric and ultraviolet absorbance detection for the determination of cyclobenzaprine in human plasma and urine. (1995), 666(1), 117-126.

[5]. Hwang, P.; Young, D.; Straughn, A.; Meyer, M.; Journal of Liquid Chromatogaphy, Quantitative Determination of Cyclobenzaprine in Human Plasma by High Pressure Liquid Chromatography, (1993), 16, 1163-1171.

[6]. Darwish, M.; Hellriegel, E. T. Clinical Therapeutics, Steady-State Pharmacokinetics of Once-Daily Cyclobenzaprine Extended Release: A Randomized, Double-Blind, 2-Period Crossover Study in Healthy Volunteers (2011), 33(6), 746-753.

[7]. Sweetman, S.C. Martindale - The Complete Drug Reference, 33rd ed., Pharmaceutical Press, London, 2002,414

[8]. Feás, X.; Ye, L.; Regal, P.; Fente, C. A.; Cepeda, A. Journal of Separation of Science, Application of dummy molecularly imprinted solid-phase extraction in the analysis of cyproheptadine in bovine urine (2009), 32(10), 1740-1747.

[9]. Feás, X.; Lei, Y.; Hosseini, S. V.; Fente, C. A. Journal of pharmaceutical and biomedical analysis, Application of dummy molecularly imprinted solid-phase extraction in the analysis of cyproheptadine in bovine urine (2009), 50(5), $1044-1049$.

[10]. Madihalli Srinivas Raghu.; Kanakapura Basavaiah. Chemical industry \& Chemical engineering quarterly, Sensitive and selective methods for the determination of cyproheptadine in tablets using N-bromosuccinimide and two dyes (2012), 18 (3), $449-458$.

[11]. Y.M. Issa, Y.M.; Rizk, M.S.; Mohammed, S.S. Analytical Letters, Performance and characteristics of new cyproheptadine hydrochloride -selective plastic membrane electrodes based on cyproheptadine tetraphenylborate .(1992), 25, 1617-1619.

[12]. Emmanuel, J.; Yegnanarayan, T. V. Indian Drugs, Colorimetric estimation of cyproheptadine hydrochloride (1982), 19(12), 505507.

[13]. Committee of Chinese Pharmacopoeia, Chinese Pharmacopoeia exegesis (Part II), Chemical Industry Press, Beijing, 1990, p. 423

[14]. Committee of Chinese Pharmacopoeia, Chinese Pharmacopoeia (PartII), Chemical Industry Press, Beijing, 1990 , p. 473.

[15]. Husseini, H.; Mitrovic, V.; Schlepper, M. J. Chromatogr. Biomed.Appl., Rapid and sensitive assay of dobutamine in plasma by high-performance liquid chromatography and electrochemical detection (1993), 620(1), 164-169.

[16]. 16.Indrayanto, G; Handayani, R. Journal of pharmaceutical and biomedical Analysis, Quantitative determination of ambroxol hydrochloride in tablets (1993), 11(8), 781-784..

[17]. Ni, Yongnian; Gu, Yao; Kokot, Serge. Chemical Papers, Simultaneous analysis of three catecholamines by a kinetic procedure: comparison of prediction performance of several different multivariate calibrations (2011), 65(6), 782-791.

[18]. Michael E. El-Kommos. Analyst, Spectrophotometric determination of dobutamine hydrochloride using 3-methylbenzothiazolin-2one hydrazone (1987), 112, 101-103.

[19]. Balfour, J. A. B.; Wiseman, L. R., Drugs, Moxifloxacin. (1999), 57(3), 363-373.

[20]. R.B.R. Muijsers, B. Jarvis. Drugs, Moxifloxacin - In Uncomplicated Skin and Skin Structure Infections (2002), 62(2), 967-973.

[21]. Djurdjevic Predrag; Ciric Andrija; Djurdjevic Aleksandra; Stankov Milena Jelikic. Journal of pharmaceutical and biomedical analysis, Optimization of separation and determination of moxifloxacin and its related substances by RP-HPLC (2009), 50(2), 117126.

[22]. Tobin, C. M.; Sunderland, J.; White, L. O.; MacGowan, A. P.; Reeves,D. S. Journal Antimicrobial B Chemotherapy, An isocratic high performance liquid chromatography (HPLC) assay for moxifloxacin, a new 8-methoxyquinolone. (1998), 42(2), $278-279$.

[23]. 23. Magno Aparecido, G.; Trindade.; Glaucia Maria da Silva.; Valdir Souza Ferreira. Microchemical Journal, Determination of moxifloxacin in tablets and human urine by square-wave adsorptive voltammetry (2005), 81(2), 209-216.

[24]. Moller, J. G., Stass, H.; Heinig, R.; Blaschke, G. Journal of Chromatography B: Biomedical Sciences and Applications, Capillary electrophoresis with laser-induced fluorescence: a routine method to determine moxifloxacin in human body fluids in very small sample volumes (1998), 716(1-2), 325-334.

[25]. Vogle's “Text book of Quantitative Analysis” Fifth Edition. 
[26]. Gurdeep-R-Chatwal, Sham K Anand "Instrumental Methods of Chemical Analysis" .

[27]. Boovizhikannan.; Thangabalan.; Kumar, Praveen.; Lavanya Gade; Inthia, Shaik.; Deepthi Choragudi.; Babu Sitty Manohar.; Palanirajan Vijayaraj Kumar. Journal of Pharmacy research, Extractive Spectrophotometric Determination of Pramipexole Dihydrochloride in Pure and Pharmaceutical Formulations (2011), 4(3), 813-814.

[28]. El-Bayoumi, A. E.; Badawy, A. M.; Kafou, A. El-Ghasem H. Bulletin of the Faculty of pharmacy (Cairo University) (2009), 47(3), $1-11$.

[29]. Lau, Y. Y; Hanson, G. D; Ichhpurani, N. Journal of chromatography. B, Biomedical applications, Determination of pramipexole (U-98,528) in human plasma and urine by high-performance liquid chromatography with electrochemical and ultraviolet detection. (1996), 683(2), 217-23,

[30]. Srinubabu, G.; Jaganbabu, K.; Sudharani, B.; Venugopal, K.; Girizasankar, G.; Rao, V. L. N. S. Chromatographia, Development and Validation of a LC Method for the Determination of Pramipexole Using an Experimental Design (2006), 64(1-2), 95100 .

[31]. United States Pharmacopoeia and National Formulary; (24th) Asian Edition, The United States Pharmacopoeia Convention Inc, U.S.A, 2709-3259.

[32]. European Pharmacopoeia, 6th Edn, (2008), Vol.2, p. 3005

[33]. B. Kalyanaramu and K. Raghubabu, Acta Ciencia Indica, Chemistry, Visible spectrophotometric methods for the estimation of sumatriptan succinate in bulk and dosage forms, (2011), 37( 2), 143-147.

[34]. Buridi, Kalyana Ramu; Raghubabu, K. International Journal of Pharmacy and Technology, A simple colorimetric determination of sumatriptan succinate from tablet dosage forms using cobalt thio cyanate," (2011), 3(1), 1411-1418.

[35]. Pourmand, M. R.; Azar, M. S.; Aghavalijamaat, M. Pharmaceutical Chemistry Journal, Development of validated UV spectrophotometric method for in vitro analysis of sumatriptan in pharmaceutical preparations in comparison with HPLC (2011), 44(10), 585-589.

[36]. Arshiya Fathima.; Sayaji Rao.; Venkateshwarlu, G. International Journal of ChemTech Research, Quantitative determination of Drugs \& Pharmaceuticals using p- Chloranilic acid as Reagent (2012), 4(1), 79-91

[37]. Harpey, C.; Clauser; P.; Labrid, C.; Freyria, J.L.; Poirier, J.P.; Cardiovasc Drug Rev, Trimetazidine, a Cellular Anti-ischemic Agent $1989,6,292-312$

[38]. Ancerewicz, J.; Migliavacca, E.; Carrupt, P. A.; Testa, B.; Bree, F.; Zini, R.; Tillement, J. P.; Labidalle, S.; Guyot, D .; ChauvetMonges, A . M.; Crevat, A.; Le Ridant, A. Free Radical Biology and Medicine. Structure-Property Relationships of Trimetazidine Derivatives and Model Compounds as Potential Antioxidants 1998, 25(1), 113-120.

[39]. Issa, Y. M.; Abou-Attia, F. M.; Abdel-Gawad, F. M.; Abdel-Hamid, S. M. Analytical Letters, Utility of Some $\pi$-Acceptors for the Spectrophotometric Determination of Trimetazidine Hydrochloride (2002), 35(3), 451-461.

[40]. Göksel Altıokka.; Kevser Kırcalı.; Hassan, Y.; Aboul Enein. Journal of Liquid Chromatography \& Related Technologies, Rapid HPLC and Direct Flow Injection Analysis Assay for the Determination of Trimetazidine $\mathrm{HCl}$ in Pharmaceutical Tablet Formulation (2006), 29(15), 2245- 2255.

[41]. Thoppil, S.O.; Cardoza, R.M.; Amin, P.D. Journal of pharmaceutical and biomedical analysis, Stability indicating HPTLC determination of Trimetazidine as bulk drug and in pharmaceutical formulations (2001), 25(1),15-20

[42]. Palilis, L.P.; Calokerinos, A.G. Anal. Chimica Acta, Analytical Applications of Chemiluminogenic Reactions (2001), 413(1-2), 175-186.

[43]. Pandeeswaran, M.; El-Mossalamy, E. H.; Elango, K. P. Journal of Solution Chemistry, Spectroscopic Studies of the Complexation of Iodine with Antihistamine Drugs in Solvents of Varying Relative Permittivity (2012), 41(12), 2091-2106.

[44]. Yadav, Ganapati D.; More, Santosh R. Current Catalysis, Cesium Modified Heteropoly Acid Supported on Clay as Catalyst in Selective Synthesis of Acetylferrocene (2012), 1(1), 32-40.

[45]. Adam, Abdel Majid A. Journal of Molecular Structure, Synthesis, spectroscopic, thermal and antimicrobial investigations of charge-transfer complexes formed from the drug procaine hydrochloride with quinol, picric acid and TCNQ (2012), 10(30), 26-39.

[46]. Raghu, Madihalli Srinivas; Basavaiah, Kanakapura Journal of the Association of Arab Universities for Basic and Applied Sciences, Optimized and validated spectrophotometric methods for the determination of levocetirizine in pharmaceuticals based on charge transfer reaction (2012), 12(1), 33-41.

[47]. Refat, M. S.; Elfalaky, A.; Elesh, E. Bulgarian Chemical Communications, Spectroscopic and physical measurements on charge transfer complex of norfloxacin drug with iodine acceptor (2011), 43(4), 516-525.

[48]. Rajendraprasad, Nagaraju; Basavaiah, Kanakapura; Vinay, Kanakapura B. Journal of the Serbian Chemical Society, Optimized and validated spectrophotometric methods for the determination of hydroxyzine hydrochloride in pharmaceuticals and urine using iodine and picric acid (2011), 76(11), 1551-1560.

[49]. Fatima, Ismat; Munawar, Munawar A.; Tasneem, Affia; Jahan, Sarwat; Khan, Misbahul A.; Ahmed, Shakeel. Journal of the Serbian Chemical Society, Antithyroid activity of some 6-(alkylsulfanyl)-9H-purines (2011), 76(10), 1355-1364.

[50]. Kumar, A. V. V. N. K. Sunil; Saradhi, S. Vijaya; Sekaran, C. Bala; Reddy, T. V. Oriental Journal of Chemistry, Visible Spectrophotometric Methods for Quantitative Determination of Doxofylline using Iodine and $\alpha, \alpha^{\prime}$-Bipyridyl as Reagents (2011), 27(2), 619-625.

[51]. Ganesh, K.; Balraj, C.; Elango, K. P. Spectrochimica Acta, Part A: Molecular and Biomolecular Spectroscopy, Spectroscopic and spectrofluorimetric studies on the interaction of irbesartan with 2,3-dichloro-5,6-dicyano-1,4-benzoquinone and iodine. (2011), 79(5), 1621-1629.

[52]. Rahman, Nafisur.; Rahman, Habibur. Spectroscopy (Amsterdam, Netherlands), Quantitative analysis of perindopril erbumine in pharmaceutical preparations by spectrophotometry via ternary complex formation with $\mathrm{Zn}$ (II) and eosin and charge transfer complexation with iodine, (2011), 25(2), 123-136.

[53]. Likussar W and Boltz DF. Anal Chem. Theory of continuous variation plots and a new method for spectrometric determination of extraction and formation constants. 43; 1971: 1265-1272.

[54]. Momoki K, Sekino J, Sato H and Yamaguchi N. Anal. Chem. Theory of curved molar ratio, plots and new linear plotting Method . 41; 1969: 1286-1299. 
<smiles>CN(C)CCC=C1c2ccccc2C=Cc2ccccc21</smiles>

a. Cyclobenzaprine $\mathrm{HCl}$<smiles>CN1CCC(=C2c3ccccc3C=Cc3ccccc32)CC1</smiles>

b. Cyproheptadine $\mathrm{HCl}$<smiles>CC(CCc1ccc(O)cc1)NCCc1ccc(O)c(O)c1</smiles>

c. Dobutamine HCL<smiles>COc1c(N2C[C@@H]3CCCN[C@@H]3C2)c(F)cc2c(=O)c(C(=O)O)cn(C3CC3)c12</smiles>

d. Moxifloxacin $\mathrm{HCl}$<smiles>CNS(=O)(=O)Cc1ccc2[nH]cc(CCN(C)C)c2c1</smiles>

f. Sumatriptan succinate<smiles>CCCN[C@H]1CCc2nc(N)sc2C1</smiles>

e. Pramipexole $\mathrm{HCl}$<smiles>COc1ccc(CN2CCNCC2)c(OC)c1OC</smiles>

g. Trimetazadine $2 \mathrm{HCl}$

Fig 1 Structures of the drugs

Table 2. Analytical Parameters for the charge transfer complexes of Iodine with Drugs.

\begin{tabular}{|c|c|c|c|c|c|c|c|}
\hline $\begin{array}{l}\text { Name of Drug } \\
\text { Property }\end{array}$ & CYC & CYP & DOB & MOX & PAM & SUM & TRI \\
\hline$\lambda \max (\mathrm{nm})$ & 366 & 366 & 366 & 366 & 366 & 366 & 366 \\
\hline $\begin{array}{l}\text { Beer's law limits } \\
\left(\mu \mathrm{gmL}^{-1}\right)\end{array}$ & $2.5-20$ & $2.5-22.5$ & $3.5-31.5$ & $50-450$ & $2.5-22.5$ & $6.4-57.6$ & $2.5-22.5$ \\
\hline $\begin{array}{l}\text { Molar absorptivity } \\
\left(\mathrm{L} \mathrm{mol}{ }^{-1} \mathrm{~cm}^{-1}\right)\end{array}$ & 1176 & 1075 & 18581 & 689.7 & 880 & 901 & 14317 \\
\hline $\begin{array}{l}\text { Formation constant, } \\
\mathrm{K}, \\
\mathrm{M}^{-1}\end{array}$ & 410 & 340 & 350 & 260 & 280 & 270 & 300 \\
\hline $\begin{array}{l}\text { Sandell's sensitivity } \\
\left(\mu \mathrm{gcm}^{-2}\right)\end{array}$ & 0.0153 & 0.0208 & 0.0181 & 0.5 & 0.0222 & 0.0555 & 0.0212 \\
\hline $\begin{array}{l}\text { Std. Dev. } \\
\text { of intercepts }\end{array}$ & 0.0105 & 0.0081 & 0.0165 & 0.00624 & 0.00929 & 0.0102 & 0.0102 \\
\hline $\operatorname{LOD}\left(\mu \mathrm{gmL}^{-1}\right)$ & 0.534 & 0.652 & 0.994 & 14.21 & 0.652 & 1.881 & 0.718 \\
\hline $\mathrm{LOQ}\left(\mu \mathrm{gmL}^{-1}\right)$ & 1.604 & 1.956 & 2.984 & 42.653 & 2.064 & 5.701 & 2.17 \\
\hline Slope, b & 0.065 & 0.049 & 0.055 & 0.002 & 0.045 & 0.018 & 0.047 \\
\hline Intercept, a & 0.074 & -0.0204 & -0.014 & 0.065 & -0.0101 & -0.009 & 0.07 \\
\hline $\begin{array}{l}\text { Correlation } \\
\text { coefficient }\end{array}$ & 0.990 & 0.989 & 0.995 & 0.997 & 0.994 & 0.980 & 0.989 \\
\hline $\begin{array}{l}\text { Regression } \\
\text { equation } \\
\mathrm{Y}=\mathrm{a}+\mathrm{bx}^{*}\end{array}$ & $\begin{array}{l}0.065+ \\
0.074 \mathrm{X}\end{array}$ & $\begin{array}{l}0.049- \\
0.0204 x\end{array}$ & $\begin{array}{l}0.055- \\
0.014 \mathrm{X}\end{array}$ & $\begin{array}{l}0.002+ \\
0.065 \mathrm{X}\end{array}$ & $\begin{array}{l}0.045- \\
0.0101 x\end{array}$ & $\begin{array}{l}0.018- \\
0.009 \mathrm{X}\end{array}$ & $\begin{array}{l}0.047+ \\
0.07 \mathrm{X}\end{array}$ \\
\hline
\end{tabular}

$\mathrm{X}=$ concentration of the drug, $\left(\mu \mathrm{gmL}^{-1}\right)$ 
Quantitative Determination of drugs \& pharnaceuticalsby using iodine as analytical reagent: A

Table 3. Recovery studies to evaluate accuracy and precision for the determination of drugs by proposed method.

\begin{tabular}{|c|c|c|c|c|c|c|c|c|}
\hline $\begin{array}{l}\text { Name } \\
\text { of the } \\
\text { Drug }\end{array}$ & $\begin{array}{l}\text { Amount } \\
\text { Taken } \\
\left(\mu \mathrm{g} \mathrm{ml}^{-1}\right)\end{array}$ & $\begin{array}{l}\text { Amount } \\
\text { Found } \\
\left(\mu \mathrm{g} \mathrm{ml}^{-1}\right)\end{array}$ & $\begin{array}{c}\% \\
\text { Recovery }\end{array}$ & RSD \% & $\begin{array}{l}\text { Proposed } \\
\text { method } \\
\text { Mean } \\
\pm \mathrm{SD} \\
\end{array}$ & $\begin{array}{l}\text { Ref } \\
\text { method } \\
\text { Mean } \\
\pm \text { SD } \\
\end{array}$ & $\begin{array}{l}\text { t-test } \\
(*)\end{array}$ & $\begin{array}{l}\text { F-test } \\
(* *)\end{array}$ \\
\hline CYC & $\begin{array}{l}4 \\
8 \\
12 \\
16\end{array}$ & $\begin{array}{l}3.97 \\
7.95 \\
12.01 \\
16.02\end{array}$ & $\begin{array}{l}99.32 \\
99.45 \\
100.08 \\
100.15\end{array}$ & 0.429 & $\begin{array}{l}99.75 \\
\pm 0.43\end{array}$ & & & \\
\hline CYP & $\begin{array}{l}4 \\
8 \\
12 \\
16\end{array}$ & $\begin{array}{l}3.86 \\
7.97 \\
11.98 \\
16.01\end{array}$ & $\begin{array}{l}96.56 \\
99.61 \\
99.82 \\
100.05\end{array}$ & 1.657 & $\begin{array}{l}99.01 \\
\pm 1.64\end{array}$ & $\begin{array}{l}\text { [199] } \\
101.4 \\
\pm 1.63\end{array}$ & $\begin{array}{l}0.066 \\
(2.57)\end{array}$ & $\begin{array}{l}1.014 \\
(4.28)\end{array}$ \\
\hline DOB & $\begin{array}{l}4 \\
8 \\
12 \\
16 \\
\end{array}$ & $\begin{array}{l}4.05 \\
7.94 \\
11.97 \\
15.94 \\
\end{array}$ & $\begin{array}{l}101.25 \\
99.20 \\
99.78 \\
99.61 \\
\end{array}$ & 0.894 & $\begin{array}{l}99.96 \\
\pm \\
0.893\end{array}$ & $\begin{array}{l}{[206]} \\
100.10 \\
\pm 0.86\end{array}$ & $\begin{array}{l}0.053 \\
(2.45)\end{array}$ & $\begin{array}{l}1.97 \\
(4.28)\end{array}$ \\
\hline MOX & $\begin{array}{l}80 \\
160 \\
240 \\
320 \\
\end{array}$ & $\begin{array}{l}79.2 \\
160.99 \\
240.56 \\
321.13 \\
\end{array}$ & $\begin{array}{l}99.00 \\
100.62 \\
100.24 \\
100.35 \\
\end{array}$ & 0.718 & $\begin{array}{l}100.05 \\
\pm 0.72\end{array}$ & $\begin{array}{l}{[130]} \\
100.21 \\
\pm 0.56\end{array}$ & $\begin{array}{l}0.403 \\
(2.45)\end{array}$ & $\begin{array}{l}1.648 \\
(4.28)\end{array}$ \\
\hline PAM & $\begin{array}{l}4 \\
8 \\
12 \\
16 \\
\end{array}$ & $\begin{array}{l}4.022 \\
8.039 \\
12.05 \\
16.04 \\
\end{array}$ & $\begin{array}{l}100.55 \\
100.49 \\
100.42 \\
100.25 \\
\end{array}$ & 0.131 & $\begin{array}{l}100.51 \\
\pm 0.76\end{array}$ & $\begin{array}{l}{[212]} \\
102.6 \\
\pm 0.78\end{array}$ & $\begin{array}{l}-1.803 \\
(2.45)\end{array}$ & $\begin{array}{l}0.0326 \\
(4.28)\end{array}$ \\
\hline SUM & $\begin{array}{l}8 \\
16 \\
24 \\
32\end{array}$ & $\begin{array}{l}8.112 \\
16.2 \\
24.16 \\
32.2\end{array}$ & $\begin{array}{l}101.39 \\
101.25 \\
100.66 \\
100.63\end{array}$ & 0.392 & $\begin{array}{l}101.39 \\
\pm 0.398\end{array}$ & $\begin{array}{l}{[218]} \\
99.92 \\
\pm 0.28\end{array}$ & $\begin{array}{l}0.491 \\
(2.45)\end{array}$ & $\begin{array}{l}2.02 \\
(4.28)\end{array}$ \\
\hline TRI & $\begin{array}{l}4 \\
8 \\
12 \\
16 \\
\end{array}$ & $\begin{array}{l}4.02 \\
8.02 \\
12.0 \\
16.0\end{array}$ & $\begin{array}{l}100.54 \\
100.25 \\
100.25 \\
100.14 \\
\end{array}$ & 0.169 & $\begin{array}{l}100.29 \\
\pm \\
0.170\end{array}$ & $\begin{array}{l}{[145]} \\
99.80 \\
\pm 0.11\end{array}$ & $\begin{array}{l}0.664 \\
(2.57)\end{array}$ & $\begin{array}{l}2.393 \\
(4.95)\end{array}$ \\
\hline
\end{tabular}

$\mathrm{t}$ - test and $* * \mathrm{~F}$-test values from literature

Table 4. Application of proposed method for the analysis of drugs in pharmaceutical formulations by proposed method.

\begin{tabular}{|c|c|c|c|c|c|c|c|c|}
\hline $\begin{array}{l}\text { Name of the } \\
\text { Drug }\end{array}$ & $\begin{array}{l}\text { Amount } \\
\text { Taken } \\
\left(\mu \mathrm{g} \mathrm{ml}^{-1}\right)\end{array}$ & $\begin{array}{l}\text { Amount } \\
\text { Found } \\
\left(\mu \mathrm{g} \mathrm{ml}^{-1}\right)\end{array}$ & $\begin{array}{c}\% \\
\text { Recovery }\end{array}$ & RSD \% & $\begin{array}{l}\text { Proposed } \\
\text { method } \\
\text { Mean } \\
\pm \mathrm{SD}\end{array}$ & $\begin{array}{l}\text { Ref } \\
\text { method } \\
\text { Mean } \\
\pm \text { SD }\end{array}$ & $\begin{array}{l}\text { t-test } \\
(*)\end{array}$ & $\begin{array}{l}\text { F-test } \\
(* *)\end{array}$ \\
\hline $\begin{array}{l}\text { CYC } \\
\text { (Flexiril) }\end{array}$ & $\begin{array}{l}4 \\
8 \\
12 \\
16\end{array}$ & $\begin{array}{l}3.98 \\
8.03 \\
12.05 \\
16.11\end{array}$ & $\begin{array}{l}99.50 \\
99.38 \\
100.42 \\
100.69\end{array}$ & 0.514 & $\begin{array}{l}100.244 \\
\pm 0.515\end{array}$ & & & \\
\hline $\begin{array}{l}\text { CYP } \\
\text { (Practin) }\end{array}$ & $\begin{array}{l}4 \\
8 \\
12 \\
16\end{array}$ & $\begin{array}{l}3.91 \\
8.14 \\
11.94 \\
16.06\end{array}$ & $\begin{array}{l}97.75 \\
101.75 \\
99.50 \\
100.37\end{array}$ & 1.677 & $\begin{array}{l}99.843 \\
\pm 1.675\end{array}$ & $\begin{array}{l}\text { [199] } \\
99.16 \\
\pm 1.31\end{array}$ & $\begin{array}{l}0.297 \\
(2.57)\end{array}$ & $\begin{array}{l}1.63 \\
(4.28)\end{array}$ \\
\hline $\begin{array}{l}\text { DOB } \\
\text { (Dobutrox) }\end{array}$ & $\begin{array}{l}4 \\
8 \\
12 \\
16 \\
\end{array}$ & $\begin{array}{l}4.06 \\
7.97 \\
12.11 \\
16.26 \\
\end{array}$ & $\begin{array}{l}101.50 \\
99.63 \\
100.92 \\
101.63 \\
\end{array}$ & 0.906 & $\begin{array}{l}100.916 \\
\pm 0.914\end{array}$ & $\begin{array}{l}{[206]} \\
99.60 \\
\pm 0.98\end{array}$ & $\begin{array}{l}-0.153 \\
(2.45)\end{array}$ & $\begin{array}{l}0.871 \\
(4.28)\end{array}$ \\
\hline $\begin{array}{l}\text { MOX } \\
\text { (Moxicip) }\end{array}$ & $\begin{array}{l}80 \\
160 \\
240 \\
320\end{array}$ & $\begin{array}{l}80.3 \\
159.76 \\
239.73 \\
320.45\end{array}$ & $\begin{array}{l}100.37 \\
99.82 \\
99.88 \\
100.14\end{array}$ & 0.2586 & $\begin{array}{l}100.05 \\
\pm 0.2587\end{array}$ & $\begin{array}{l}{[130]} \\
100.68 \\
\pm 0.17\end{array}$ & $\begin{array}{l}0.657 \\
(2.45)\end{array}$ & $\begin{array}{l}2.317 \\
(4.28)\end{array}$ \\
\hline $\begin{array}{l}\text { PAM } \\
\text { (Parpex) }\end{array}$ & $\begin{array}{l}4 \\
8 \\
12 \\
16 \\
\end{array}$ & $\begin{array}{l}4.022 \\
8.039 \\
12.05 \\
16.04\end{array}$ & $\begin{array}{l}100.55 \\
100.49 \\
100.42 \\
100.25 \\
\end{array}$ & 0.131 & $\begin{array}{l}100.51 \\
\pm 0.76\end{array}$ & $\begin{array}{l}{[212]} \\
102.6 \\
\pm 0.78\end{array}$ & $\begin{array}{l}-1.802 \\
(2.45)\end{array}$ & $\begin{array}{l}0.03269 \\
(4.28)\end{array}$ \\
\hline $\begin{array}{l}\text { SUM } \\
\text { (Sumatriptan) }\end{array}$ & $\begin{array}{r}8 \\
16 \\
24 \\
32 \\
\end{array}$ & $\begin{array}{l}8.06 \\
16.06 \\
23.96 \\
32.13 \\
\end{array}$ & $\begin{array}{l}100.75 \\
100.38 \\
99.83 \\
100.41 \\
\end{array}$ & 0.375 & $\begin{array}{l}100.314 \\
\pm 0.378\end{array}$ & $\begin{array}{l}{[218]} \\
99.78 \\
\pm 0.37\end{array}$ & $\begin{array}{l}0.0322 \\
(2.45)\end{array}$ & $\begin{array}{l}1.048 \\
(4.28)\end{array}$ \\
\hline $\begin{array}{l}\text { TRI } \\
\text { (Carvidon) }\end{array}$ & $\begin{array}{l}4 \\
8 \\
12 \\
16\end{array}$ & $\begin{array}{l}3.96 \\
8.05 \\
12.11 \\
15.97 \\
\end{array}$ & $\begin{array}{l}99.00 \\
100.63 \\
100.92 \\
99.81 \\
\end{array}$ & 0.862 & $\begin{array}{l}100.088 \\
\pm 0.863\end{array}$ & $\begin{array}{l}{[145]} \\
99.98 \\
\pm 0.59\end{array}$ & $\begin{array}{l}0.584 \\
(1.17)\end{array}$ & $\begin{array}{l}2.134 \\
(3.932)\end{array}$ \\
\hline
\end{tabular}

$* \mathrm{t}$ - test and $* * \mathrm{~F}$-test values from literature 
Quantitative Determination of drugs \& pharnaceuticalsby using iodine as analytical reagent: A

Table 1. The range of concentration of the drugs used for charge transfer complexation with Iodine

\begin{tabular}{|l|l|l|}
\hline Drugs & Working concentration & Range \\
\hline Cyclobenzaprine $\mathrm{HCl}$ & & $2.5-20 \mu \mathrm{g} \mathrm{ml}^{-1}$ \\
Cyproheptadine HCl & $2.5 \mu \mathrm{g} \mathrm{ml}^{-1}$ & $2.5-22.5 \mu \mathrm{g} \mathrm{ml}^{-1}$ \\
Dobutamine HCL & $2.5 \mu \mathrm{g} \mathrm{ml}^{-1}$ & $3.5-31.5 \mu \mathrm{g} \mathrm{ml}^{-1}$ \\
Moxifloxacin HCl & $3.5 \mu \mathrm{g} \mathrm{ml}^{-1}$ & $50-450 \mu \mathrm{g} \mathrm{m}^{-1}$ \\
Pramipexole $\mathrm{HCl}$ & $50 \mu \mathrm{g} \mathrm{ml}^{-1}$ & $2.5-22.5 \mu \mathrm{g} \mathrm{ml}^{-1}$ \\
Sumatriptan succinate & $2.5 \mu \mathrm{g} \mathrm{ml}^{-1}$ & $6.4-57.6 \mu \mathrm{g} \mathrm{ml}^{-1}$ \\
Trimetazadine $2 \mathrm{HCl}$ & $6.4 \mu \mathrm{g} \mathrm{ml}^{-1}$ & $2.5-22.5 \mu \mathrm{g} \mathrm{ml}^{-1}$ \\
\hline
\end{tabular}
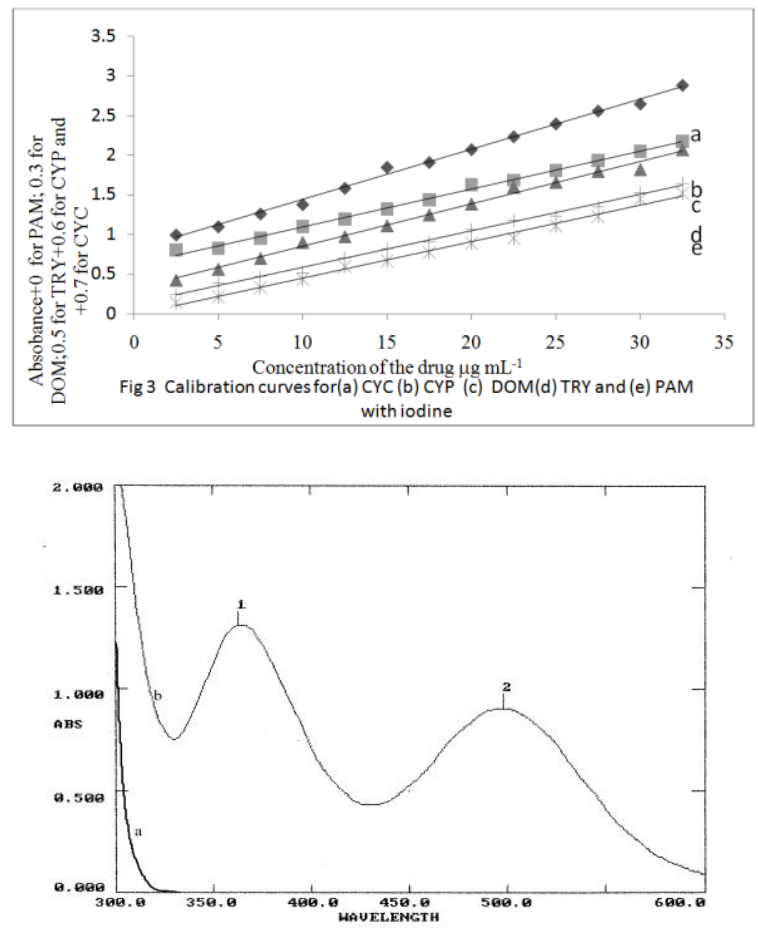

Fig.2 Typical absorption spectra of iodine and its CT complex(b) with drug(a)

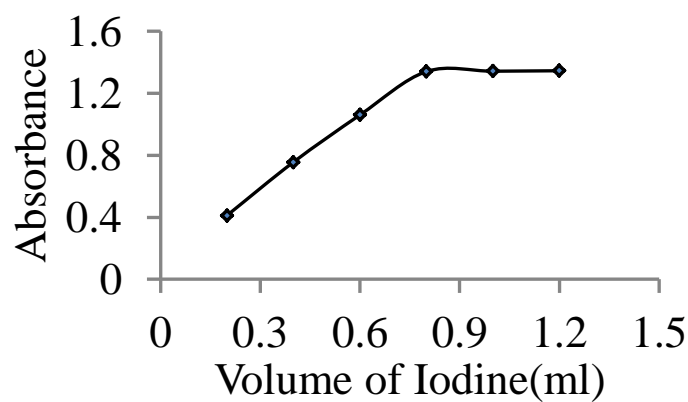

Fig.4 Influence of the volume of Iodine (typical)

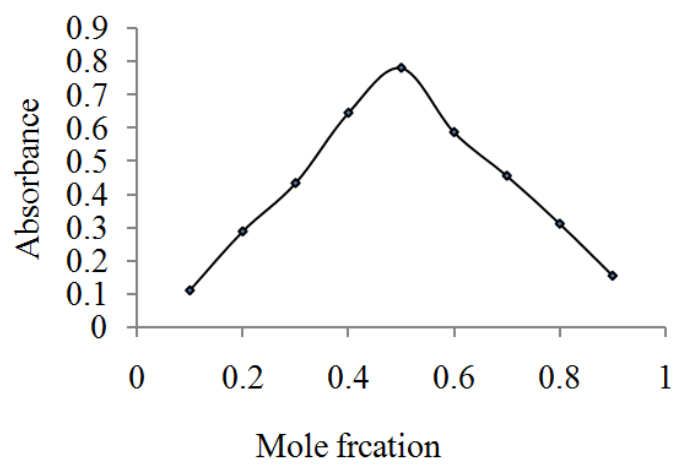

Fig. 5 Job's Continuous-variation study of drug-Iodine system (typical) 